\title{
Mesoclemmys dahli (Zangerl and Medem 1958) - Dahl's Toad-Headed Turtle, Carranchina, Tortuga Montañera
}

\author{
German Forero-Medina ${ }^{1,2}$, Olga V. Castaño-Mora ${ }^{3}$, Gladys Cárdenas-Arevalo ${ }^{3}$, \\ and Guido Fabián Medina-Rangel ${ }^{3}$ \\ ${ }^{1}$ Wildlife Conservation Society, Calle 2 \# 42-23, Cali, Colombia [forecroc@yahoo.com]; \\ ${ }^{2}$ Turtle Survival Alliance, Calle 2 \# 42-23, Cali, Colombia; \\ ${ }^{3}$ Instituto de Ciencias Naturales, Universidad Nacional de Colombia, Bogotá, Colombia \\ [ovcastanom@unal.edu.co,gladysc4@gmail.com,gfmedinar@unal.edu.co]
}

\begin{abstract}
Summary. - Dahl's Toad-headed Turtle (Family Chelidae) is a small to medium-sized freshwater turtle (carapace length to $297 \mathrm{~mm}$ ) endemic to small streams and pools with a restricted range within the Tropical Dry Forest Biome of northern Colombia. It is omnivorous, feeding mainly on snails, crustaceans, and aquatic insects. Mesoclemmys dahli spends considerable time on land, particularly during the dry season when it may estivate. Home ranges may be as large as 31 ha during a year cycle and it may use or cross streams, riparian vegetation and contiguous areas, pastures, and lentic water bodies in the middle of open areas. Very little is known about its reproductive ecology in the wild, but nesting may occur from October to March, coupled with dry climatic conditions in the region. Although it may be abundant at some locations within the core of its range (Córdoba), only a few (less than 5) populations are known, and abundance (16-170 turtles/ha) in the eastern populations (Cesar) is generally lower than reported for other South American chelids. The species is threatened because of the high degree of transformation of its habitat for human activities such as fires, urban expansion, agriculture, and cattle. There are no populations known that inhabit wellpreserved dry forests, and there is no known presence of the species in any formally protected area. Habitat restoration and establishment of a protected area for the species are measures required for its long-term persistence.

Distribution.-Colombia. Restricted to northern Colombia,north of the Andes in the departments of Córdoba, Sucre, Atlántico, Bolívar, Magdalena, and Cesar.

Synonymy. - Phrynops (Batrachemys) dahli Zangerl and Medem 1958, Phrynops dahli, Batrachemys dahli, Phrynops nasutus dahli, Mesoclemmys dahli.

SubSPECIES. - No subspecies have been described.

STATuS. - IUCN 2013 Red List: Critically Endangered (CR B1+2c; assessed 1996); TFTSG Draft Red List: Endangered (EN, assessed 2011); CITES: Not Listed; Colombian Red Data Book: Endangered (B1 + 2bc).
\end{abstract}

Taxonomy. - Mesoclemmys dahli was originally described as Phrynops (Batrachemys) dahli by Zangerl and Medem in 1958, based on four specimens collected "near" Sincelejo, Sucre, Colombia. The epithet honors the collector, ichthyologist, and professor George Dahl from the Liceo Bolivar of Sincelejo. Medem (1966) later published data on the ecology and behavior of the species and provided information regarding its geographic range. Additionally, he collected a few more individuals that are deposited at the Instituto de Ciencias Naturales of the Universidad Nacional de Colombia.

For many years the taxon was referred to as simply Phrynops dahli, as the use of subgenera did not gain wide acceptance. McCord et al. (2001) conducted a study of the broad genus Phrynops and suggested resurrecting and elevating the old subgenus Batrachemys, designating the species Batrachemys dahli. Their analyses were not accepted by some authors (Joyce et al. 2004 and others), mainly because the phylogenetic relationships of South American chelids are not well resolved, and the species was subsequently placed in the broader genus Mesoclemmys, also an old subgenus of Phrynops. Vargas-Ramírez et al. (2012) analyzed sequences of the mitochondrial cytochrome $b$ gene and identified a close relationship and weak genetic divergence between $M$. dahli and M. zuliae from Venezuela. Currently, the Turtle Taxonomy Working Group (2012) recognizes the species as Mesoclemmys dahli.

Description. - Mesoclemmys dahli is a small to medium-sized freshwater turtle. Maximum carapace length (CL) is $297 \mathrm{~mm}$ recorded from a female from Cesar. The species is characterized by having a proportionally large head with a pointed snout and a relatively thin and very long neck; tympanic head width is $23-26 \%$ of the carapace length (Rueda-Almonacid et al. 2007). 


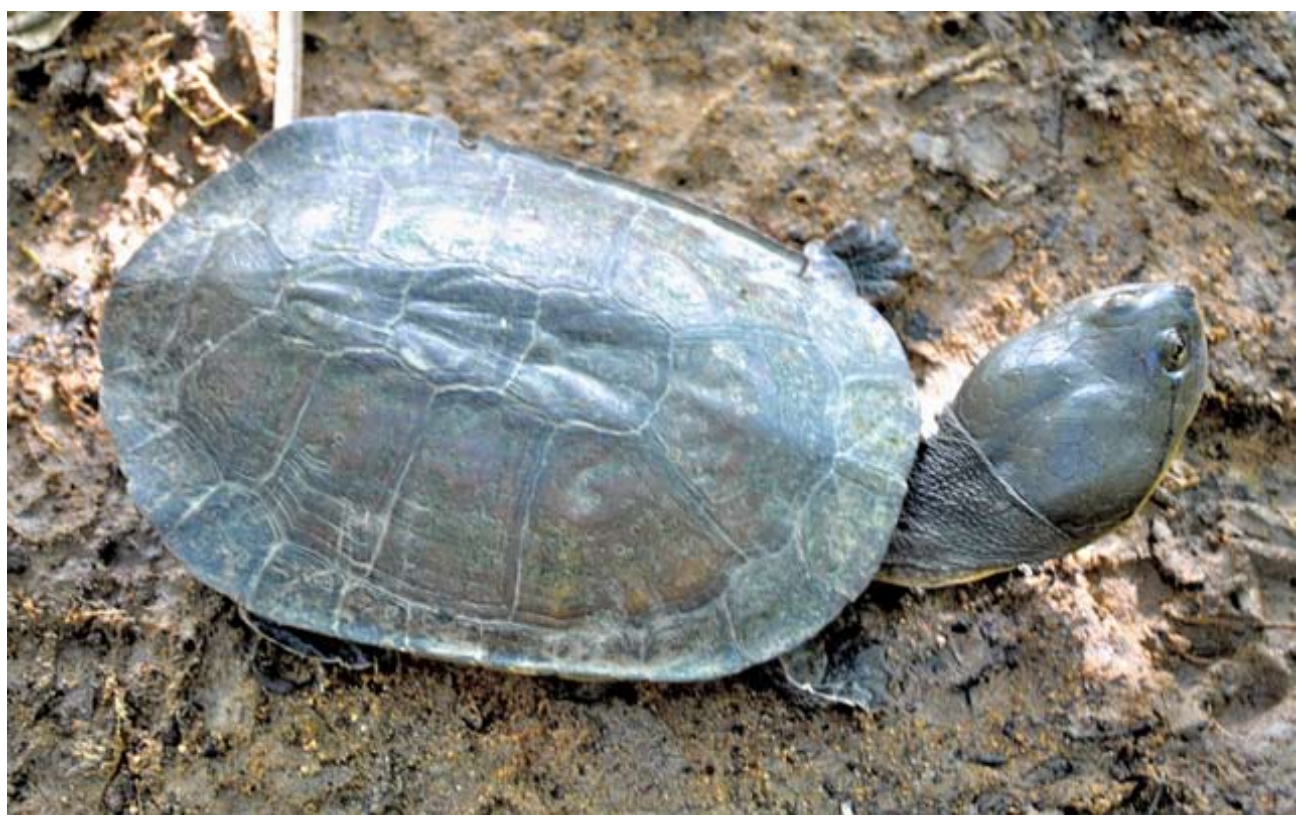

Figure 1. Adult female Mesoclemmys dahli. Note the thin black head stripe. Photo by German Forero-Medina.

The species has a compressed carapace, which is olivebrown or gray, sometimes presenting a medial keel that is barely visible, mainly in juveniles. In adults there is a longitudinal dorsal depression that encompasses vertebral 2,3, and 4 . The plastron is strong and long but somewhat narrow, particularly in males (Medem 1966), and has a well-defined posterior notch.

The head is large, flattened, and very wide at the temporal region, because of the well-developed cranial muscles that penetrate through the lateral emargination of the skull. The species does not have corneous shields on the head, which is dorsally gray and light yellow or cream laterally, from the nostrils to the tympanic membrane. There are two thin, dark gray or black head stripes that extend from the nostril to the neck, passing through each eye. The head and limbs are yellow ventrally, like the plastron, sometimes with a reddish or orange color.

There is marked sexual dimorphism, with males (mean $\mathrm{CL}=172 \mathrm{~mm}$, maximum $\mathrm{CL}=229 \mathrm{~mm}[\mathrm{n}=10]$ ) smaller than females $($ mean $C L=185.5 \mathrm{~mm}$, maximum $C L=297 \mathrm{~mm}$ $[n=35])$. Males have longer and thicker tails, particularly anterior to the cloaca, and a more pronounced anal notch. Males also have reddish color on the throat, neck, and scales of the forelimbs (Medem 1966).

Distribution. - Mesoclemmys dahli is endemic to northern Colombia and is restricted to a small geographic

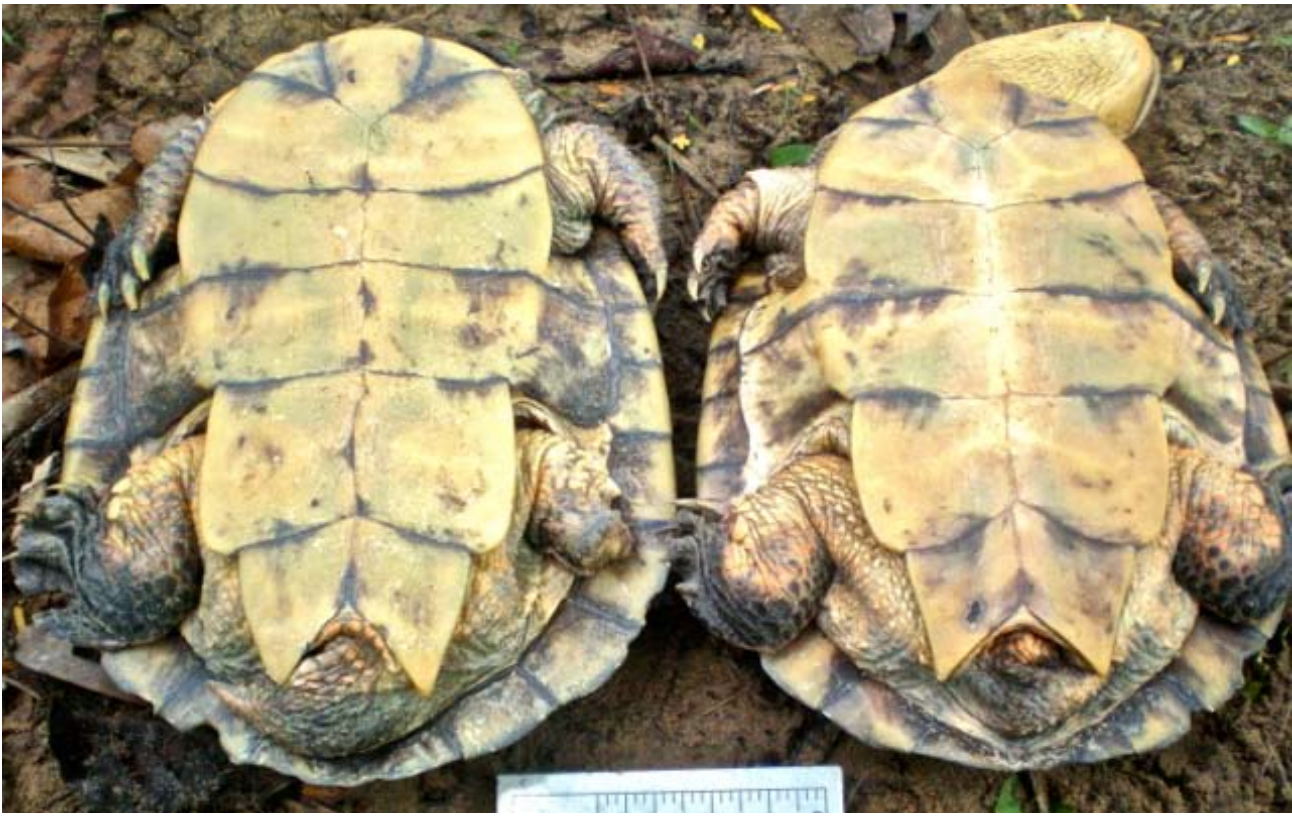

Figure 2. Ventral view of adult male (left) and female (right) Mesoclemmys dahli. Photo by German Forero-Medina. 


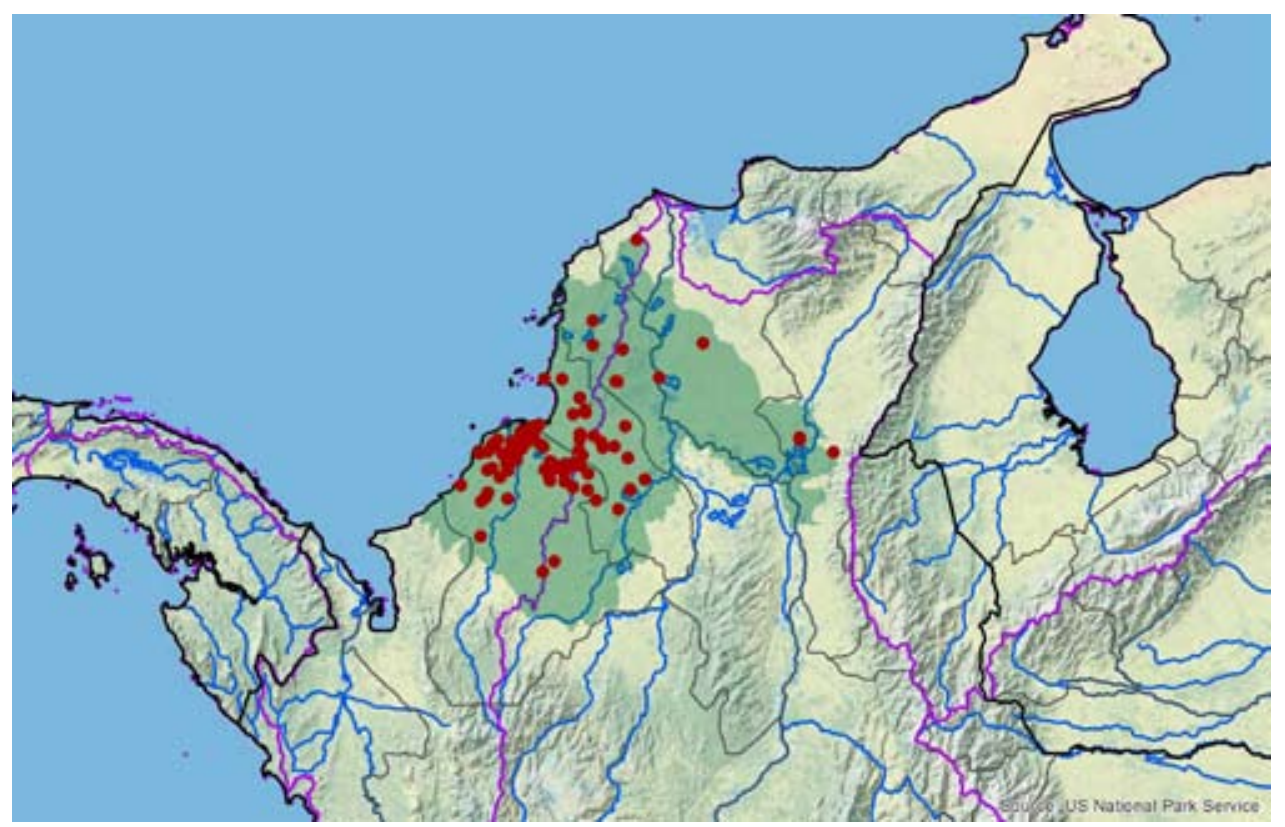

Figure 3. Distribution of Mesoclemmys dahli in northern Colombia in northwestern South America. Purple lines = boundaries delimiting major watersheds (level 3 hydrologic unit compartments $-\mathrm{HUCs}$ ); red dots = museum and literature occurrence records of native populations based on Iverson (1992), plus more recent and authors' data; green shading = projected native distribution based on GIS-defined HUCs constructed around verified localities and then adding HUCs that connect known point localities in the same watershed or physiographic region, and similar habitats and elevations as verified HUCs (Buhlmann et al. 2009), and adjusted based on authors' subsequent data.

area. It is the only species from the family Chelidae to occur northwest of the Andes. For over 40 years after its description (Zangerl and Medem 1958), it was only known from the region of the type locality, with all observations $(<10)$
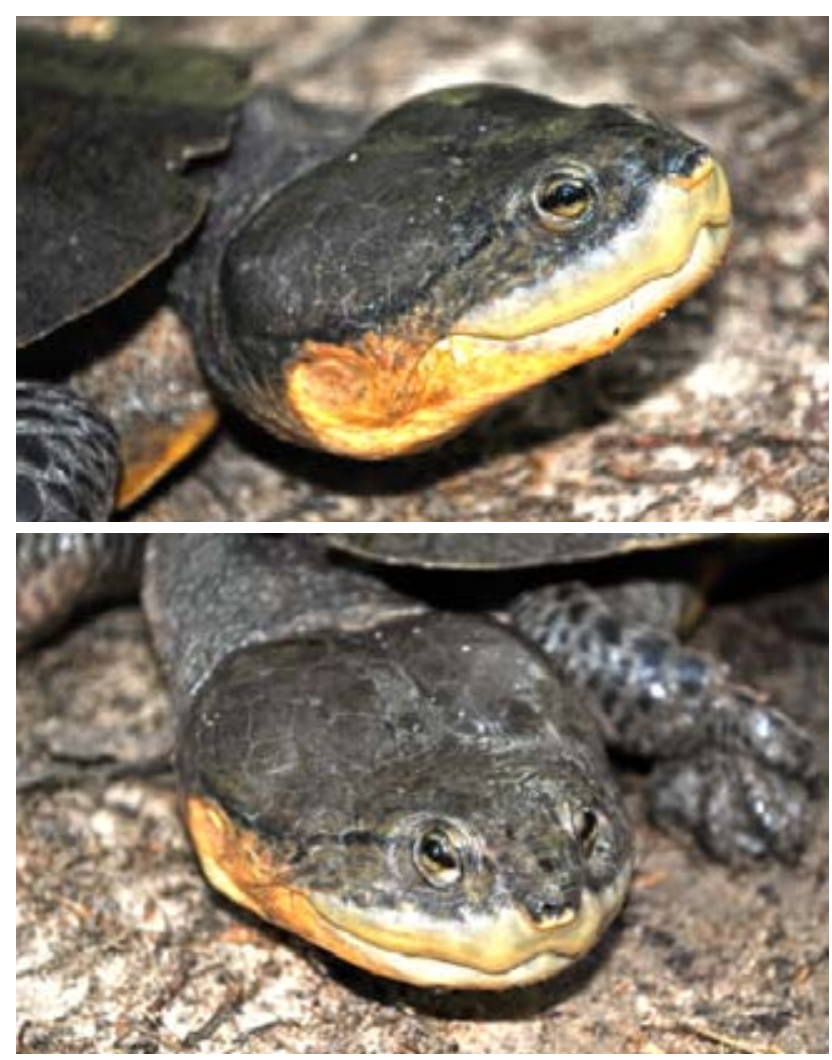

Figure 4. Large head and wide temporal region of Mesoclemmys dahli. Photos by German Forero-Medina. restricted to the department of Sucre(Medem 1966, Ernst and Barbour 1989; Iverson 1992, Ceballos-Fonseca 2000).

It has more recently been found to also occur in the departments of Córdoba, Bolívar,Atlántico, and most recently, Cesar(Castaño-Mora and Medem 2002, Rueda-Almonacidet al.2007, Medina-Rangel and Forero-Medina 2008, MedinaRangel et al. 2011). In this way it has now been documented that its range is larger than when originally discovered. For this reason it has been removed from the list of the world's 25 most threatened turtles (Turtle Conservation Fund 2003; IUCN/SSC Tortoise and Freshwater Turtle Specialist Group 2007; Chelonian Conservation Coalition 2011).

Recent niche models suggest that the species could also occur in the Department of Antioquia and therefore could occur over an area of approximately $32,000 \mathrm{~km}^{2}$ (Forero-Medina

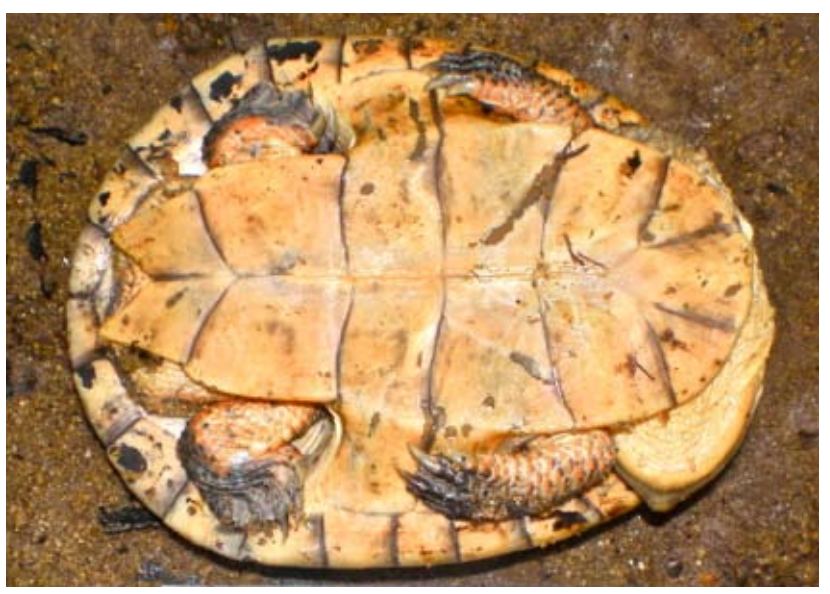

Figure 5. Juvenile Mesoclemmys dahli. Photo by German ForeroMedina. 
et al. 2012), although most of this area has been degraded of its original vegetation and land cover. This raises questions regarding the viability of populations across this range.

Habitat and Ecology. - The natural habitat identified for the species consists of small pools and permanent or temporal streams with low water flow and good vegetation cover along the edges within the Tropical Dry Forest Biome (Medem 1966; Rueda-Almonacid 2007; Forero-Medina et al. 2012). However, individuals have also been recorded in swamps and artificial water ponds with abundant aquatic vegetation and small pools formed in open pastures during the rainy season (Medem 1966; Castaño-Mora and Medem 2002; Rueda-Almonacid et al. 2007; Forero-Medina et al. 2011; Medina-Rangel et al. 2011).

A recent study conducted in Cesar has indicated that the species is associated with small, first order streams, with water flow lower than $0.22 \mathrm{~m} / \mathrm{s}$ and low clarity (less than $32 \mathrm{~cm}$ ) (Forero-Medina et al. 2012). The streams where the species was found were also wider (1-10 m) and had deeper pools than streams where it was not observed. Within the streams where the species occurs, its presence at particular sites was associated with a high canopy cover by the riparian vegetation $(>82 \%)$ and deeper pools $(>78 \mathrm{~cm})$. Additionally, there was a positive correlation between water depth and carapace length, which suggests that juveniles tend to inhabit shallower waters.

The species is known to estivate; when on land it remains hidden under leaf litter, tree roots, and spiny shrubs (Rueda-Almonacid et al. 2004; Forero-Medina et al. 2011). Rueda et al. (2006) have reported individuals remaining buried under leaf litter for up to 120 days. In order to avoid desiccation during estivation it retains large amounts of water in its bladder (Rueda-Almonacid et al. 2004). The authors have found specimens estivating as far as $1 \mathrm{~km}$ from the closest water body, or hidden under trash and leaf litter in people's backyards. Occasionally, several individuals have been observed estivating very close to each other $(0.5-1 \mathrm{~m})$,

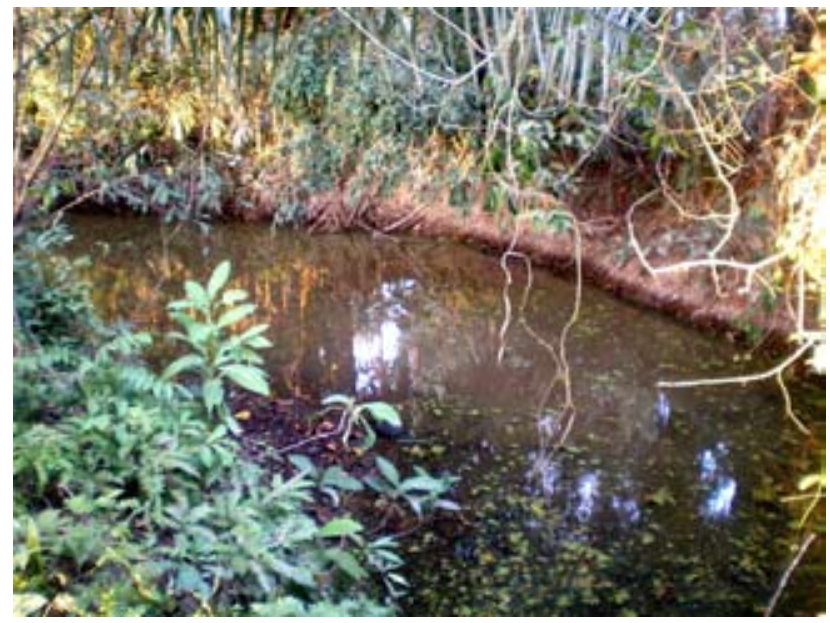

Figure 6. Typical habitat of Mesoclemmys dahli in Chimichagua, Cesar. Photo by German Forero-Medina. although apparently not all of them had initiated estivation at the same time. At the end of the dry season one can find some very thin, dry turtles with empty stomachs close to turtles with good weight, aquatic algae on the carapace, and food in their stomachs (Castaño-Mora et al. 2005).

This raises the question of whether animals from the same water body estivate together, or whether there are sites with suitable conditions for estivation used by turtles from different water bodies. When they do not estivate they can remain in the same water body, if it persists, or move to others. During late dry season some individuals have been found in overheated, highly eutrophicated pools without riparian vegetation (Castaño-Mora et al. 2005).

Occasionally, individuals can be observed walking on land, including close to human habitations (Castaño-Mora and Medem 2002; Rueda-Almonacid et al. 2004). For this reason in some areas the species is called tortuga montañera (mountain turtle), referring to its habit of walking in higher areas that do not flood.

Rueda-Almonacid et al. (2004) reported that the mean straight carapace length of hatchlings from one clutch (n = 9) was $44.4 \mathrm{~mm}$, straight carapace width was $35.6 \mathrm{~mm}$, and mean weight was $13.6 \mathrm{~g}$. The authors reported that four captive hatchlings had an average growth of $15.2 \mathrm{~mm}$ (range, 7.2-20.6 mm) in 154 days, with a daily growth rate of $0.04-0.14 \mathrm{~mm} /$ day.Medem (1966) considered as juveniles individuals with a carapace length of less than $130 \mathrm{~mm}$.

Reproduction. - Very little is known regarding the reproductive ecology of the species.Medem (1966) observed that the mating season occurred mainly in June and July for captive animals in Villavicencio, Colombia, with copulation taking place in shallow waters. He suggested that the number

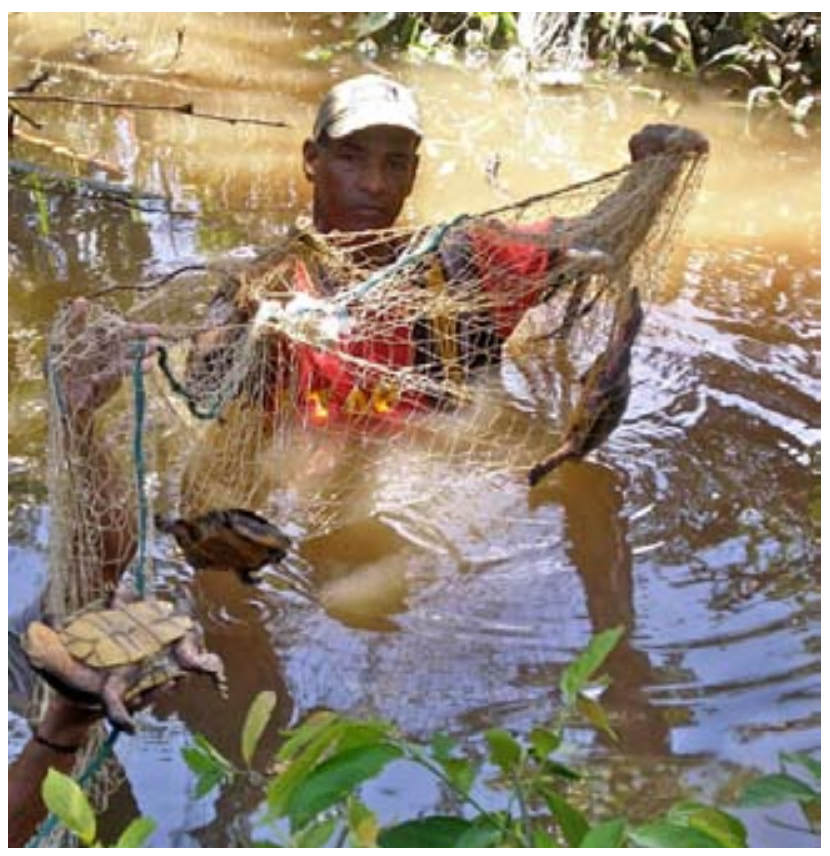

Figure 7. Capturing Mesoclemmys dahli using seine nets $(2.5 \mathrm{~cm}$ mesh size) in Chimichagua, Cesar. Photo by Gladys Cárdenas-Arevalo. 
of eggs per clutch was usually not higher than six, and the possibility of several clutches per year, as indicated by the ovules in different degree of development that he found in several females at different times of the year. Based on this, he reported a main nesting season between September and October. Egg dimensions reported in his study varied from $28 \times 24 \mathrm{~mm}$ to $36 \times 29 \mathrm{~mm}$.

Rueda-Almonacid et al. (2004) indicated that mating and nesting seasons are not well known in Córdoba, but suggested that hatchlings emerge from April to May. RuedaAlmonacid et al. (2007) reported that in Córdoba oviposition takes place during the dry months (October to March).

Rueda-Almonacid et al. (2004) recorded a nest in Córdoba located ca. $1 \mathrm{~km}$ from the closest stream, with 12 eggs, with an average egg size of $34.3 \times 28.8 \mathrm{~mm}$ and an average weight of $16.3 \mathrm{~g}$. The same authors reported an incubation period of four months and hatching success of $92 \%$ for these eggs incubated under $e x$-situ conditions. Rueda-Almonacid et al. (2006) described changes in adult coloration associated with the onset of the reproductive season: males turned orange on the plastron, legs and neck, and during June and July became reddish, while some females only turned orange and almost none acquired the reddish coloration.

Movements and Home Range. - Rueda-Almonacid et al. (2004) reported a difference in home ranges between the climatic seasons. During the dry months (October to March), females $(n=5)$ had a home range between 0.03 and $10.69 \mathrm{ha}$, and during the rainy season (April to September) between 0.49 and $12.04 \mathrm{ha}$. The authors did not report individual home ranges for males. Strong rains cause major floods and currents in the streams that can carry turtles along, contributing to significant displacements of some individuals. According to Forero-Medina et al. (2011), annual home range varies between 9.2 and 22.5 ha using a fixed Kernel estimator. Although the authors did not find any significant differences in the mean movements between dry (December to February) and rainy (March to November) seasons, the largest movements were recorded during the transition from the rainy to the dry season.

Predators. - Castaño-Mora et al. (2005) reported natural predators of M. dahli to include the Spectacled Caiman(Caiman crocodilus), the Southern Caracara (Caracara plancus), the Snail Kite (Rostrhamus sociabilis), the Great Black Hawk (Buteogallus urubitinga), and the Gold Tegu (Tupinambis teguixin). Rueda-Almonacid et al. (2004) indicated egg predators to include the Crab-eating Raccoon (Procyon cancrivorus) and the Gold Tegu; and predators of juveniles and hatchlings to include several aquatic birds, particularly herons (Casmerodius albus, Tigrisoma spp.), storks (Dichromanassa rufescens), and prey birds such as hawks and eagles (Pandion haliaetus, Buteo spp., Spizaetus ornatus, etc.); and of adults the Spectacled Caiman and small carnivores (Felis spp.).
Diet. - Mesoclemmys dahli is omnivorous and feeds in the water, at night, primarily on snails (Pomacea spp.), crustaceans, crabs, aquatic insects, tadpoles, frogs, small fish, dead animals, and occasionally plant material (Medem 1966; Castaño-Mora and Medem 2002; Rueda-Almonacid et al. 2004, 2007). Castaño-Mora et al. (2005) found ants in the stomach contents of some animals that were estivating, suggesting they could also feed on land.

The species is mainly nocturnal (Medem 1966), although it can be captured during the day using baited hooks, which suggests some type of diurnal activity. On sunny days some individuals may come out to bask on logs or floating plant material. At night, besides feeding and foraging in the water, some animals may come out on land to search for other water bodies or refuge in the forest (Rueda-Almonacid et al. 2004; Forero-Medina et al. 2011).

Population Status. - Studies conducted in Córdoba suggest that the species is locally abundant in this part of its range (Rueda-Almonacid et al. 2004). The authors reported 8-18 turtles captured per km of stream sampled, resulting in densities of around 20-60 turtles/ha. In some artificial pools the relative densities estimated in this fashion were as high as 500 turtles/ha. Estimated population sizes at three streams in Córdoba were 30, 77, and 178 individuals (Rueda-Almonacid et al.2006). In Cesar, relative abundances expressed as number of individuals captured per distance sampled were not higher than 10 turtles/ha, and population sizes estimated using mark-recapture and statistical models varied between 16(95\% CI, 7-30) and 175 (95\% CI,32-298) individuals (Forero-Medina et al. 2011). Densities based on the estimated number of individuals in the population at this locality ranged from 16 turtles/ha in April to 170 turtles/ha in June.

These population densities are lower than the ones reported for other populations of M. dahli in Colombia and other South American chelids. Apparently the species is more abundant in Córdoba than in Cesar, possibly because the population in Cesar is located on the eastern margin of the range (Forero-Medina et al. 2012).

Threats to Survival. - The species is threatened because of its small range and the high degree of degradation of its habitat for human activities such as fires, chemical pollution of the water, urban expansion, agriculture, and cattle (Medem 1966; De La Ossa-Velasquez 1998; Castaño-Mora and Medem 2002; Rueda-Almonacid et al. 2007; CastañoMora et al. 2010; Sampedro-Marin et al. 2012).

The Tropical Dry Forest Biome, the species' typical habitat, has been subjected to continuous deforestation and fragmentation caused by human activities (IAvH 1998; IDEAM et al. 2007; Rangel-Ch. 2010). This biome is one of the most heavily impacted and least protected by Colombia's protected area network (Forero-Medina and Joppa 2010). Rangel-Ch. (pers. comm.) has estimated that the lowlands 
of the Colombian Caribbean, where M. dahli occurs, may have lost more than $80 \%$ of their natural land cover.

The riparian vegetation of the streams the species inhabits has been subjected to intense deforestation or has been completely eradicated in most cases (Rueda-Almonacid et al. 2004; Forero-Medina et al. 2011). This has caused overheating and drying of some of the pools that previously persisted during the dry season, and reduction of sites for estivation, with unknown consequences for the species.

Mesoclemmys dahli was first discovered in swamps where the city of Sincelejo (Sucre) lies today, but these swamps have since been transformed into urban areas. At all sites where populations have been detected, its habitat has been degraded and experiences regular artificial fires, which cause mortality in adults and nests (Rueda-Almonacid et al. 2004, 2007). Rueda-Almonacid et al. (2004) reported that one fourth of individuals found during their research had burns caused by fires.

Aditionally, at some localities in Córdoba, individuals that are captured incidentally during fishing activities are killed by fishermen (Rueda-Almonacid et al. 2004). At other localities, indigenous people actively search for turtles or local people capture them in order to trade them for food, particularly manioc (Manihot esculenta) (Castaño-Mora et al. 2005). A few locals kill any turtle they find saying that they eat their ducks or small chickens (Rueda-Almonacid et al. 2004).

It has been suggested that the introduction of domestic animals (cats, dogs, pigs) and the movement of other chelonians by humans could have negative impacts on M. dahli through predation or introduction of pathogens and invasive species (Rueda-Almonacid et al. 2004). However, there are no studies supporting this hypothesis. It is unknown whether remnant populations are viable in the long term and there are no known populations within formally protected areas.

Conservation Measures Taken. - In Córdoba, Conservation International developed an important conservation program involving local communities which included habitat restoration and environmental education (Rueda-Almonacid et al. 2007). Such programs should be continued and extended to other areas where the species occurs. In Cesar, researchers from the Universidad Nacional de Colombia and other organizations have worked with local people and visited public schools to raise awareness among kids about the endemic character of the species and its high level of threat (Forero-Medina and Cardenas 2009).

The species is currently assessed as Critically Endangered on the IUCN Red List, but has recently been provisionally reassessed as Endangered by the IUCN/SSC Tortoise and Freshwater Turtle Specialist Group as a result of the discovery of its greater extent of occurrence. It is not listed on the CITES Appendices. No known populations occur in any protected areas.
Conservation Measures Proposed. - Recent studies conducted in Córdoba and Cesar have improved the knowledge of the species' geographic range, natural history, and threats (Castaño-Mora and Medem 2002; RuedaAlmonacid et al. 2004, 2007; Castaño-Mora et al. 2005, Forero-Medina et al. 2011, 2012). Although these studies have contributed to basic aspects of the species' ecology, studies on its genetic structure and variability, reproductive ecology, nesting sites, clutch size, duration of incubation period, sexual selection, and the effects of human activities on its populations and their viability over the long term are urgently needed.

Restoration of the species' habitat at sites of known occurrences is urgently needed. Riparian vegetation is an important resource for the species and it needs to be recovered or restored at streams where $M$. dahli has been reported. Areas contiguous to the streams should also be protected as they are commonly used by the species and are part of its home range (Rueda-Almonacid et al. 2004; Forero-Medina et al. 2011).

Mechanisms to avoid deaths during artificial fires should also be implemented to reduce mortality in some areas. Finally, it is important to establish a protected area of some kind (public or private) to provide the species with some formal protection. Rueda-Almonacid et al. (2006) suggested that the wetlands at Bonito-Severá and Pareja in the Department of Córdoba are an important area for the conservation of the species.

Captive Husbandry. - The only published information regarding captive individuals of this species comes from Medem (1966). He kept several individuals at the Instituto de Ciencias Naturales in Bogotá and others at a green house in Cartagena. He made observations on their behavior, diet and reproductive ecology, as some of the females laid eggs in captivity. Most of the individuals reportedly died some months after capture.

Current Research. - Wildlife Conservation Society and the Turtle Survival Alliance are continuing population studies of the species initiated by the Universidad Nacional in Cesar, and are starting a project sponsored by Ecopetrol, seeking to determine the best areas for implementing conservation actions for the species. This will be done studying the genetic structure of the species, and the habitat conditions of the remaining populations, to determine if the species requires protection at multiple sites, and which of these are viable for conservation actions. These efforts are focused on preserving the species' typical habitat, the Tropical Dry Forest.

Acknowledgments. - We thank the People's Trust for Endangered Species for supporting research on the species, the Grupo de Biodiversidad y Conservacion from the Instituto de Ciencias Naturales, Universidad Nacional de Colombia, 
Corpocesar, Wildlife Conservation Society, and the Turtle Survival Alliance for funding and support.

\section{LITERATURE CITED}

Buhlmann, K.A.,Akre, T.S.B., Iverson, J.B., Karapatakis, D., MitTERMEIER, R.A., GEORGES, A., RHODIN, A.G.J., VAN DiJK, P.P., AND GibBons, J.W. 2009. A global analysis of tortoise and freshwater turtle distributions with identification of priority conservation areas. Chelonian Conservation and Biology 8(2):116-149.

Castaño-Mora, O.V. and Medem, F. 2002. Batrachemys dahli. In: Castaño-Mora, O.V. (Ed.) Libro Rojo de Reptiles de Colombia. Libros Rojos de Especies Amenazadas de Colombia. Bogotá: Instituto de Ciencias Naturales-Universidad Nacional de Colombia, Ministerio del Medio Ambiente, Conservación InternacionalColombia, pp. 77-79.

Castaño-Mora, O.V., Cárdenas-Arévalo, G., Gallego-García, N., AND Rivera-Diaz, O. 2005. Protección y conservación de los quelonios continentales en el departamento de Córdoba. Bogotá, Colombia: Convenio No. 28. Universidad Nacional de Colombia Instituto de Ciencias Naturales-Corporación Autónoma Regional de los Valles del Sinú y del San Jorge CVS, 185 pp.

Castaño-Mora, O.V., Cárdenas-Arévalo, G., and Gallego, N. 2010. Uso actual de la fauna silvestre en la ciénaga Grande del Bajo Sinú, Córdoba. In: Rangel-Ch., J.O. (Ed.). Colombia Diversidad Biótica X: Los Humedales del Departamento de Córdoba, Colombia. Instituto de Ciencias Naturales-Universidad Nacional de Colombia-CVS, pp. 429-455.

Ceballos-Fonseca, C.P. 2000. Tortugas (Testudinata) marinas y continentales de Colombia. Biota Colombiana 1(2):187-194.

DeLa Ossa-Velasquez,J.1998.Phrynops dahli: a little known turtle endemic to the caribbean coast of Colombia. Reptilia 3:47-50.

ERnst, C.H. AND BARbOUR, R.W. 1989. Turtles of the World. Washington, DC: Smithsonian Institution Press, 313 pp.

Forero-Medina, G.A. and CÁrdenas-Arévalo, G. 2009. Movement patterns and conservation of the endemic Dahl's toad-headed turtle Mesoclemmys dahli in Cesar, Colombia. Final report to People's Trust for Endangered Species, $29 \mathrm{pp}$.

Forero-Medina, G. AND JoPPA, L. 2010. Representation of global and national conservation priorities by Colombia's Protected Area Network. PLoS ONE 5(10): e13210.

Forero-Medina, G., Cárdenas-Arévalo, G., and Castaño-Mora, O.V. 2011. Abundance, home range, and movement patterns of the endemic species Dahl's Toad-headed Turtle (Mesoclemmys dahli) in Cesar, Colombia. Chelonian Conservation and Biology 10(2):228-236.

Forero-Medina, G., Cárdenas-Arévalo, G., and Castaño-Mora, O.V. 2012. Habitat modeling of Dahl's toad-headed turtle (Mesoclemmys dahli) in Colombia. Herpetological Conservation and Biology 7(2):313-322.

IAvH [Instituto de Investigación de Recursos Biológicos AlexANDER von Humboldt]. 1998. Bosque seco Tropical (Bs-T) en Colombia. Programa de inventario de la Biodiversidad, Grupo de exploraciones y monitoreo ambiental GEMA, $24 \mathrm{pp}$.

IDEAM,IGAC,IAvH,INVEMAR,I.SINCHI,AND IAP.2007.Ecosistemas continentales, costeros y marinos de Colombia.Bogota,Colombia: Instituto de Hidrología, Meteorología y Estudios Ambientales, InstitutoGeográfico Agustín Codazzi,Instituto de Investigación de Recursos Biológicos Alexander von Humboldt, Instituto de Investigaciones Ambientales del Pacífico, Instituto de Investigaciones Marinas y Costeras José Benito Vives De Adréis, and Instituto Amazónico de Investigaciones Científicas Sinchi, 276 pp.
IUCN/SSC Tortoise and Freshwater Turtle Specialist Group. 2007. Turtles in Trouble: The World's Top 25 Most Endangered Tortoises and Freshwater Turtles - 2007. http://www.iucn-tftsg. org/top-25-2007/.

IVERSON,J.B. 1992.ARevisedChecklist withDistribution Maps of the Turtles of the World. Richmond, IN: Privately printed, $363 \mathrm{pp}$.

Joyce, W.G., Parham, J.F., And Gauthier, J.A. 2004. Developing a protocol for the conversion of rank-based taxon names to phylogenetically defined clade names, as exemplified by turtles. Journal of Paleontology 78(5):989-1013.

McCord, W.P., Joseph-Ouni, M., AND Lamar, W.W. 2001 . A taxonomic reevaluation of Phrynops (Testudines; Chelidae) with the description of two new genera and a new species of Batrachemys. Revista de Biología Tropical 49(2):715-764.

MEDEM,F. 1966. Contribuciones al conocimiento sobre la ecología y distribución geográfica de Phrynops (Batrachemys) dahli; (Testudinata, Pleurodira, Chelidae). Caldasia 9(45):467-489.

Medina-Rangel, G.F. and Forero-Medina, G.A. 2008. Geographical distribution. Mesoclemmys dahli. Herpetological Review 39:366.

Medina-Rangel, G.F., Cárdenas-Arévalo, G., and Castaño-Mora, O.V. 2011. Anfibios y reptiles de los alrededores del complejo cenagoso de Zapatosa, departamento del Córdoba, Colombia. In: Rangel-Ch.,J.O.(Ed.).Colombia Diversidad Biótica.Publicación Especial No.1. Bogotá,Colombia: Grupo de Biodiversidad y Conservación, Instituto de Ciencias Naturales, Universidad Nacional de Colombia-CORPOCÓRDOBA, 105 pp.

Rangel-Ch., J.O. (Ed.). 2010. Colombia Diversidad Biótica X: Los Humedales del Departamento de Córdoba, Colombia. Instituto de Ciencias Naturales-Universidad Nacional de Colombia-CVS, 816 pp.

Rueda-Almonacid, J.V., Galvis-Peñuela, P., LóPez-Ospina, C., AND LoZANO, G.Y. 2004. Estudio sobre la distribución geográfica y el estatus ecológico de la tortuga carranchina (Batrachemys dahli) en el bajoSinú,Departamento deCórdoba.Final report to Corporación Autónoma Regional de los Valles del Sinú y San Jorge - CVS and Conservación Internacional-Colombia, 53 pp.

Rueda-Almonacid,J.V.,LoZano,G.Y., and Galvis-PeÑUEla,P. 2006. Plan de acción para la conservación de la tortuga carranchina (Batrachemysdahli) en el departamento de Cordoba.Corporacion Autonoma Regional de los Valles del Sinu y San Jorge, Conservacion Internacional, $41 \mathrm{pp}$.

Rueda-Almonacid, J.V., Carr, J.L., Mittermeier, R.A., RodrígueZMahecha, J.V., Mast, R.B., Vogt, R.C., Rhodin, A.G.J., De La OSSA-VelásqueZ,J.,RuedA,J.N., ANDMITTERMEIER,C.G.2007.Las Tortugas y los Cocodrilianos de los Países Andinos del Trópico. Bogotá, Colombia: Editorial Panamericana, Formas e Impresos, Serie de Guías Tropicales de Campo No. 6, Conservación Internacional, $538 \mathrm{pp}$.

SAmpedro-Marín,A.,Tobios-Atencio,P., and Trespalacio-Solana,T. 2012. Estado de conservación de la tortuga "carranchina" (Batrachemys dahli), en localidades del departamento de Sucre, Colombia. Revista Colombiana de ciencias Animales 4(1):69-88.

Turtle Conservation Coalition [Rhodin, A.G.J., Walde, A.D., Horne, B.D., van Dijk, P.P., Blanck, T., and Hudson, R. (Eds.)]. 2011. Turtles in Trouble: The World's 25+ Most Endangered Tortoises andFreshwaterTurtles - 2011.Lunenburg,MA: IUCN/SSC Tortoise and Freshwater Turtle Specialist Group, Turtle Conservation Fund, Turtle Survival Alliance, Turtle Conservancy, Chelonian Research Foundation, Conservation International, Wildlife Conservation Society, and San Diego Zoo Global, 54 pp.

Turtle Conservation Fund. 2003. Top 25 Turtles on Death Row: new list spotlights most endangered turtles and action plan to save 
them. Conservation International, Press Release 15 May 2003, http://www.turtleconservationfund.org/top-25/.

Turtle Taxonomy Working Group [van Dijk, P.P., Iverson, J.B., ShafFer, H.B., Bour, R., AND RHODIN, A.G.J.]. 2012. Turtles of the world, 2012 update: annotated checklist of taxonomy, synonymy, distribution, and conservation status. In: Rhodin, A.G.J., Pritchard, P.C.H., van Dijk, P.P., Saumure, R.A., Buhlmann, K.A., Iverson, J.B., and Mittermeier, R.A. (Eds.). Conservation Biology of Freshwater Turtles and Tortoises: A Compilation Project of the IUCN/SSC Tortoise and Freshwater Turtle Specialist Group. Chelonian Research Monographs No. 5, pp. 000.243-000.328, doi:10.3854/crm.5.000.checklist.v5.2012, www.iucn-tftsg.org/cbftt/.

Vargas-Ramírez, M., Michels, J., Castaño-Mora, O.V., CÁrdenasArévalo, G., Gallego-García, N., and Fritz, U. 2012. Weak genetic divergence between the two South American toad-headed turtles Mesoclemmys dahli and M. zuliae (Testudines: Pleurodira:
Chelidae). Amphibia-Reptilia 33:373-385.

Zangerl, R. AND MEDEM, F. 1958. A new species of chelid turtle, Phrynops (Batrachemys) dahli, from Colombia. Bulletin of the Museum of Comparative Zoology 119:375-390.

\section{Citation Format for this Account:}

Forero-Medina, G., Castaño-Mora, O.V., Cárdenas-Arevalo, G., and Medina-Rangel, G.F.2013.Mesoclemmys dahli (Zangerl and Medem 1958)-Dahl's Toad-Headed Turtle, Carranchina, Tortuga Montañera. In: Rhodin, A.G.J., Pritchard, P.C.H., van Dijk, P.P., Saumure, R.A., Buhlmann, K.A., Iverson, J.B., and Mittermeier, R.A. (Eds.). Conservation Biology of Freshwater Turtles and Tortoises: A Compilation Project of the IUCN/SSC Tortoise and Freshwater Turtle Specialist Group. Chelonian Research Monographs No. 5, pp. 069.1-069.8, doi:10.3854/crm.5.069.dahli. v1.2013, http://www.iucn-tftsg.org/cbftt/. 